\title{
Biological Activity Study on Anti-oxidant, Whitening, and Anti-inflammatory Effects of Astragalus membranaceus Ethanol Extracts and Bioconversion Extracts
}

\author{
Hye-Kyung Bae, Seon-Hee You \\ Department of Bioengineering, Konkuk University, Seoul, Korea
}

\author{
"Corresponding author: Seon-Hee You, \\ Department of Bioengineering, Konkuk \\ University, 120 Neungdong-ro, Gwangjin-gu, \\ Seoul 05029, Korea \\ Tel.: +82 24503523 \\ Fax: +82 234365594 \\ Email: yoush4843@naver.com
}

Received July 26, 2017

Revised August 28, 2017

Accepted September 12, 2017

Published December 30, 2017

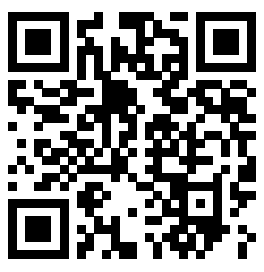

\begin{abstract}
Purpose: This study aimed to analyze the applicability of Astragalus membranaceus ethanol extracts (AM) and Astragalus membranaceus bioconversion extracts (AMB) as an ingredient in functional cosmetics. Methods: 2,2-Diphenyl-1-picrylhydrazyl (DPPH) radical elimination, melanogenesis inhibition, melanogenesis associated transcription factor (MITF), and tyrosinase expression were evaluated. Furthermore, nitric oxide (NO) synthesis inhibition and its inhibitory effects on the expression of cyclooxygenase 2 (COX2) were evaluated. Results: There were DPPH radical scavenging activities over $51 \%$ in $0.5 \%$ concentration of both samples. Both extraction methods had excellent melanin biosynthesis inhibition effects, and inhibitory effects on MITF expression were confirmed in the AMB. In addition, in the AMB, excellent inhibitory effects on NO production were confirmed, but COX2 inhibition effects were not great. Conclusion: The AMB, which has anti-oxidant activity effects, is expected to be used as material for various functional cosmetic products that have whitening effects through MITF expression inhibition and antiinflammatory effects through NO production inhibition.
\end{abstract}

Keywords: Anti-oxidant effects, Anti-inflammatory effects, Astragalus membranaceus, Bioconversion, Melanin

\section{Introduction}

황기(黃芪, Astragali Radix)는 콩과(Leguminosae)에 속하 는 다년생 초본 식물이며, 학명은 Astragalus membranaceus Bunge로 한방에서는 매우 중요한 한약재 중의 하나로 알려 져 있다(Lee et al., 2008). 국내에서는 강원도, 경상북도의 고 산에 주로 분포되어 있으며, 국내에서 주로 발견되는 제주황 기(Astragalus membranaceus var. alpinus Nakai), 개황기 (Astragalus uliginosus L), 자주황기[Astragalus dahuricus (Pall.) DC.], 정선황기(Astragalus koraiensis Y.N.Lee), 그 외 염주황기(Astragalus membranaceus var. mandshuricus Nakai), 설령황기(Astragalus setsureianus Nakai), 자주개 황기(Astragalus adsurgens), 갯황기(Astragalus sikokianus Nakai), 긴꽃대황기(Astragalus schelichovii Turcz.) 등이
알려져 있고, 특히 편경(扁苹)황기[Astragalus complanatus R. Brown (Leguminosae)]는 주로 약용으로 이용되고 있다 (Bang et al., 2004).

황기의 주요 생리활성 성분으로는 미량광물질(trace elements), 사포닌(saponins), 아미노산(amino acids), 다당 류(polysaccharides), 플라보노이드(flavonoids) 등이 보고 되었으며(Ma et al., 2002), 황기의 뿌리에는 감마아미노뷰 티르산( $\gamma$-aminobutyric acid, GABA)과 알파아미노부티르 산( $\alpha$-aminobutyric acid), 아스파라긴(asparagine), 베타인 (betaine), 베타시토스테롤( $\beta$-sitosterols), 글루콘산(gluconic acid), 리놀레산(linoleic acid) 등의 여러 생리활성물질이 함 유되어 있다고 알려져 있다(McKenna et al., 2002). 황기와 관련한 선행 연구로는 항산화 활성 연구(Kang et al., 2006; Kim \& Yang, 2001), 혈관 형성 촉진 효과(Seo et al., 2007), 
항염증 효과(Ryu et al., 2008), 동물 모델에서의 외과적 창 상에 대한 치료 효과(Han et al., 2005), 보습 및 항노화 효과 (Jung et al., 2006; Kim et al., 2007) 등이 보고 되고 있다.

최근 천연 소재를 활용한 기능성 화장품의 소재 개발 연구가 진행되고 있으며(Ha \& You, 2016; Han et al., 2016; Yu \& $\mathrm{Kim}, 2017)$, 천연 소재 개발과 더불어 소재에 대한 다양한 방 법을 활용한 추출법을 적용하여 생물학적 활용성을 높이기 위 한 연구가 활발하게 진행되고 있다. 특히 다양한 추출법 중 주 목받고 있는 방법이 발효와 효소사용을 통해 유효한 성분의 함 량을 높이는 생물전환 방법으로서, 생물전환은 생물학적 활성 이 뛰어난 특정 유효성분들의 함량을 높여서 효능을 증가시키 고 유효성분이 피부에 빠르게 흡수될 수 있도록 하는데 목적을 두고 있으며, 현재까지 생물전환을 통한 긍정적인 연구 사례가 보고 되고 있는 실정이다. 따라서 본 연구에서는 $70 \%$ 에탄올 로 추출한 황기 추출물과 효소처리를 이용하여 생물전환된 황 기 추출물을 이용하여 항산화 활성을 확인하고, neutral red (NR) assay를 이용한 B16F10 세포와 RAW 264.7 세포에서의 세포 생존율을 확인하였다. 미백 효과를 확인하고자 $\mathrm{B} 16 \mathrm{~F} 10$ 세포에서의 멜라닌 생성 억제 효과와 MITF, tyrosinase 활성 억제 효과를 측정하였고, $\mathrm{NO}$ 생성 억제 및 $\mathrm{COX} 2$ 활성 억제를 통한 항염증 효과를 평가함으로써 $70 \%$ 에탄올 추출법과 생물 전환 추출법을 활용한 황기 추출물이 기능성 화장품 소재로서 의 활용 가능성을 확인하고자 하였다.

\section{Methods}

\section{1. 실험재료}

\section{1) 에탄올 추출}

건조된 황기는 제천한방약초(Korea)에서 구입하였으며, $70 \%$ 에탄올(Duksan Pure Chemicals, Korea)은 황기 시 료 무게의 10 배를 가하여 $37^{\circ} \mathrm{C}, 100 \mathrm{rpm}$ 인큐베이터(Jeio Tech, Korea) 안에서 $72 \mathrm{~h}$ 동안 추출하였다. 얻어진 추출물 의 상층액을 정제하고, 추출용매인 에탄올을 감압 농축(Eyela, Tokyo Rikakikai, Japan)을 통해 제거한 뒤 동결 건조 (ilShinBioBase, Korea)하여 황기 에탄올 추출물(Astragalus membranaceus ethanol extracts, AM)을 제조하였다. 건조 중량에 대한 추출 고형분의 수율은 $12.33 \%$ 로 확인되었다.

\section{2) 생물전환}

위와 같이 획득한 황기 에탄올 추출물에 복합 효소 (Accellerase ${ }^{\circledR} 1500$; DuPont, USA)를 처리하여 효소에 의한 가수분해 후, $50^{\circ} \mathrm{C}$ high temperature drying oven (Changshin Science, Korea)에서 진공 건조하여 $50 \%$ oxyresveratrol을 포함하는 황기 생물전환 추출물(Astragalus membranaceus bioconversion extracts, AMB)을 제조하였 다.

\section{3) 세포주 및 세포배양}

본 실험에 사용한 세포주인 B16F10 melanoma, RAW 264.7 macrophage 세포는 한국세포주은행(Korean Cell Line Bank, Korea)에서 구입하여 사용하였으며, high glucose Dulbecco's modified Eagle's medium (high glucose DMEM; Sigma-Aldrich, USA) 배지에 10\% fetal bovine serum (FBS; Sigma-Aldrich)과 1\% penicillin/ streptomycin (100 IU/mL, $50 \mu \mathrm{g} / \mathrm{mL}$; Sigma-Aldrich)를 첨가하여 $37^{\circ} \mathrm{C}, 5 \%$ 의 $\mathrm{CO}_{2}$ 습윤 배양기(Jeio $\left.\mathrm{Tech}\right)$ 에서 배양 하였다.

\section{2. 항산화 효과 측정}

$\mathrm{AM}$ 과 $\mathrm{AMB}$ 의 항산화 효과를 확인하기 위해 Blois (1958) 방법을 이용하여 $\mathrm{DPPH}$ 라디칼 소거능을 측정하였다. 각 시료 의 최종농도가 $0.05,0.1,0.25,0.5 \%$ 가 되도록 에탄올에 희 석한 후 $10 \mathrm{mM} \mathrm{DPPH}$ (Sigma-Aldrich) 용액 $180 \mu \mathrm{L}$ 와 시 료액 $20 \mu \mathrm{L}$ 를 96 well plate에 분주하여 $37^{\circ} \mathrm{C}$ 에서 $30 \mathrm{~min}$ 동 안 반응시킨 다음 microplate reader (Synergy HT, BioTek Instruments, USA)를 이용하여 $517 \mathrm{~nm}$ 에서 흡광도를 측정 하였다. 양성 대조군으로는 $0.01,0.1,1 \%$ 농도의 ascorbic acid (Sigma-Aldrich)를 사용하였다.

$\mathrm{DPPH}$ 라디칼 소거능 $(\%)=1-\frac{\text { 시료첨가군의 흡광도 }(517 \mathrm{~nm})}{\text { 시료무첨가군의 흡광도 }(517 \mathrm{~nm})} \times 100$

\section{NR assay를 이용한 세포 생존율 측정}

$\mathrm{AM}$ 과 $\mathrm{AMB}$ 가 세포 생존율에 미치는 영향을 확인하기 위하 여 NR assay를 이용하여 측정하였다. B16F10 세포와 RAW 264.7 세포를 96 well plate에 $3 \times 10^{4}$ cells/well의 농도로 분 주하여 $24 \mathrm{~h}$ 배양 후 $\mathrm{AM}$ 과 $\mathrm{AMB}$ 를 3.12, 6.25, 12.5, 25, $50 \mu \mathrm{g} / \mathrm{mL}$ 의 농도로 희석하여 각 well plate에 처리하여 48 $\mathrm{h}$ 동안 배양하였다. $48 \mathrm{~h}$ 후 무 혈청 배지에 $1 \% \mathrm{NR}$ solution (Sigma-Aldrich) 용액이 첨가된 배양액으로 교환하여, $3 \mathrm{~h}$ 동안 배양한 후 phosphate buffered saline (PBS; SigmaAldrich)에 10\% formaldehyde (Sigma-Aldrich) 용액을 첨 가하여 각 well에 $100 \mu \mathrm{L}$ 씩 분주하여 $20 \mathrm{~min}$ 동안 고정하였 다. NR desorb solution [1\% glacial acetic acid (SigmaAldrich), 49\% ethanol (Duksan Pure Chemicals), 50\% distilled water]을 각 well에 $100 \mu \mathrm{L}$ 씩 분주하여 세포 내의 $\mathrm{NR}$ 을 추출한 다음 microplate reader를 이용하여 $540 \mathrm{~nm}$ 에 서 흡광도를 측정하였다. 본 실험의 세포 생존율은 다음의 식 
에 따라 산출하였다.

$$
\text { 세포생존율 }(\%)=\frac{\text { 시료첨가군의 흡광도 }(540 \mathrm{~nm})}{\text { 시료무첨가군의 흡광도 }(540 \mathrm{~nm})} \times 100
$$

\section{4. 멜라닌 생합성 억제능 측정}

$\mathrm{AM}$ 과 $\mathrm{AMB}$ 의 멜라닌 생합성 억제능은 B16F10 melanoma 세포를 이용하여 측정하였다(Lim et al., 2003). B16F10 세 포를 96 well plate에 각 well 당 $2 \times 10^{3}$ cells/well의 농도로 분주하고 $24 \mathrm{~h}$ 동안 배양하였다. 배양 후 멜라닌 생성을 촉진 하기 위하여 $5 \% \mathrm{FBS}$ 와 $100 \mathrm{nM} \alpha$-melanocyte-stimulating hormone ( $\alpha$-MSH; Sigma-Aldrich)가 포함된 배지로 교체 하였고, 각 시료를 $3.12,6.25,12.5,25 \mu \mathrm{g} / \mathrm{mL}$ 의 농도로 처 리하여 $72 \mathrm{~h}$ 배양하였다. 멜라닌 생성량은 microplate reader 를 이용하여 $405 \mathrm{~nm}$ 에서 흡광도를 측정하였고, 멜라닌 생성 억제량은 $100 \mathrm{nM} \alpha-\mathrm{MSH}$ 로 처리한 대조군과 비교하여 백분 율로 표시하였다. 양성 대조군으로는 arbutin (Alfa Aesar, $\mathrm{USA})$ 을 $100 \mu \mathrm{g} / \mathrm{mL}$ 농도로 사용하였다.

멜라닌 생합성 억제능 $(\%)=\frac{\text { 시료첨가군의 흡광도 }(405 \mathrm{~nm})}{\text { 시료무첨가군의 흡광도 }(405 \mathrm{~nm})} \times 100$

\section{NO 생성 억제능 측정}

$\mathrm{AM}$ 과 $\mathrm{AMB}$ 의 $\mathrm{NO}$ 생성 억제능은 세포 배양액내 $\mathrm{NO}$ 양을 nitrite $\left(\mathrm{NO}_{2}^{-}\right)$와 nitrate $\left(\mathrm{NO}_{3}^{-}\right)$형태로 측정하는 Green et al. (1982)의 방법을 이용하여 측정하였다. RAW 264.7 세 포를 96 well plate에 well당 $5 \times 10^{4}$ cells/well의 농도로 분 주하고, $24 \mathrm{~h}$ 동안 배양 후 배지를 제거한 다음 $1 \mu \mathrm{g} / \mathrm{mL}$ lipopolysaccharide (LPS; Sigma-Aldrich)가 처리된 DMEM 배지에 시료를 $3.75,7.5,15,20 \mu \mathrm{g} / \mathrm{mL}$ 의 농도별로 처리하 여 $48 \mathrm{~h}$ 동안 배양하였다. 배양된 세포 배양 상층액 $100 \mu \mathrm{L}$ 와 griess reagent (Sigma-Aldrich) $100 \mu \mathrm{L}$ 을 새로운 96 well plate에서 혼합하여 차광된 상태에서 $10 \mathrm{~min}$ 반응시킨 후 microplate reader를 이용하여 $540 \mathrm{~nm}$ 에서 흡광도를 측 정하였다. $\mathrm{NO}$ 생성 억제능은 다음의 식에 따라 산출하였으며, LPS 군과 비교하였다.

$\mathrm{NO}$ 생성 저해능 $(\%)=\frac{\text { 시료첨가군의 흡광도 }(540 \mathrm{~nm})}{\text { 시료무첨가군의 흡광도 }(540 \mathrm{~nm})} \times 100$

\section{Western blotting}

$\mathrm{AMB}$ 에 대한 B16F10 melanoma 세포 내 MITF, tyrosinase 활성 억제능 및 RAW 264.7 세포 내 COX2 단 백질 발현 억제능을 확인하기 위해 Western blotting을 실 시하였다. B16F10 melanoma 세포와 RAW 264.7 세포 를 $1.5 \times 10^{5}$ cells/well의 농도로 분주하여 $24 \mathrm{~h}$ 동안 배양 한 후 B16F10 melanoma 세포에 $100 \mathrm{mM} \alpha-\mathrm{MSH}$ 와 RAW
264.7 세포에 $1 \mu \mathrm{g} / \mathrm{mL}$ LPS이 처리된 DMEM 배지에 각 각 B16F10 melanoma 세포에 $\mathrm{AMB}$ 를 $25 \mu \mathrm{g} / \mathrm{mL}$, RAW 264.7 세포에 $\mathrm{AMB}$ 를 $20 \mu \mathrm{g} / \mathrm{mL}$ 의 농도로 처리한 다음 두 세포 모두 동일한 방법으로 $48 \mathrm{~h}$ 배양한 세포를 수확하여 $\mathrm{PBS}$ 로 세척 후 radioimmunoprecipitation assay (RIPA) buffer [50 mM Tris-Cl (0.2\% Tween 20, pH 7.5), 50 $\mathrm{mM}$ sodium chloride $(\mathrm{NaCl}), 1 \% \mathrm{NP}-40,0.5 \%$ sodium deoxycholate $\left(\mathrm{C}_{24} \mathrm{H}_{39} \mathrm{NaO}_{4}\right), 0.1 \%$ sodium dodecyl sulfate (SDS), protease inhibitor cocktail; Roche, Switzerland] 로 첨가하여 세포를 용해한 후 상등액을 회수하였다. 단백 질을 변성시키기 위하여 SDS sample buffer [14.4 mM 2-mercaptoethanol, $60 \mathrm{mM}$ Tris ( $\mathrm{pH} \mathrm{6.8),} \mathrm{25 \%} \mathrm{glycerol,}$ $2 \% \mathrm{SDS}, 0.1 \%$ bromophenol blue]를 첨가한 후 sodium dodecyl sulfate-polyacrylamide gel electrophoresis (SDS$\mathrm{PAGE}$ )를 이용하여 단백질을 분자량별로 분리하였다. 분리 된 단백질은 $100 \mathrm{~V}$ 의 조건에서 nitrocellulose membrane (Whatman, GE Healthcare Life Sciences, UK)으로 transfer한 다음 membrane에 옮겨진 단백질을 $5 \%$ skim milk 용액에서 blocking 한 후 $1 \times$ tris-buffered saline with tween 20 [TBST; $150 \mathrm{mM} \mathrm{NaCl}, 10 \mathrm{mM}$ Tris-Cl $(0.2 \%$ Tween 20, $\mathrm{pH}$ 7.5)]에 희석한 $\beta$-actin primary antibody (1:10,000, Sigma-Aldrich), anti-MITF antibody produced in rabbit (1:3,000, Sigma-Aldrich), antityrosinase antibody produced in mouse (1:3,000, SigmaAldrich)를 처리하고 $24 \mathrm{~h}$ 동안 교반하였다. Secondary antibody는 anti-mouse IgG antibody, anti-rabbit IgG antibody (Santa Cruz Biotechnology, USA)을 사용하여 30 $\min$ 교반하였으며, 교반이 완료된 membrane은 TBST로 세 척하였다. 세척이 완료된 후 실험용 필름(Konica Minolta, Japan)에서 SuperSignal ${ }^{\circledR}$ West Pico Chemiluminescent Substrate (Pierce, Thermo Fisher Scientific, USA)을 처리 하여 필름에 감광을 유도한 다음 암실에서 자동현상기( $\mathrm{QX}-$ 130II, Konica Minolta)를 이용하여 현상하였다. 현상된 필 름상의 단백질양은 ImageJ (National Institutes of Health, USA)를 이용하여 band 농도차이를 비교하였다.

\section{7. 통계처리}

본 실험의 연구 결과는 평균 \pm 표준편차(mean \pm standard deviation, $\mathrm{M} \pm \mathrm{SD}$ )로 표기하였으며, 통계 처리는 Statistical Package for the Social Sciences (SPSS) window version 17.0 (IBM, USA)을 이용하여 분석하였다. 유의성 검증은 Student's $t$-test를 실시하였고, $p$ 값이 0.05 미만일 때 통계적 으로 유의한 차이가 있는 것으로 판정하였다. 모든 실험은 동 일한 조건하에 독립적으로 3 회 이상 실시하여 실험 결과를 얻 


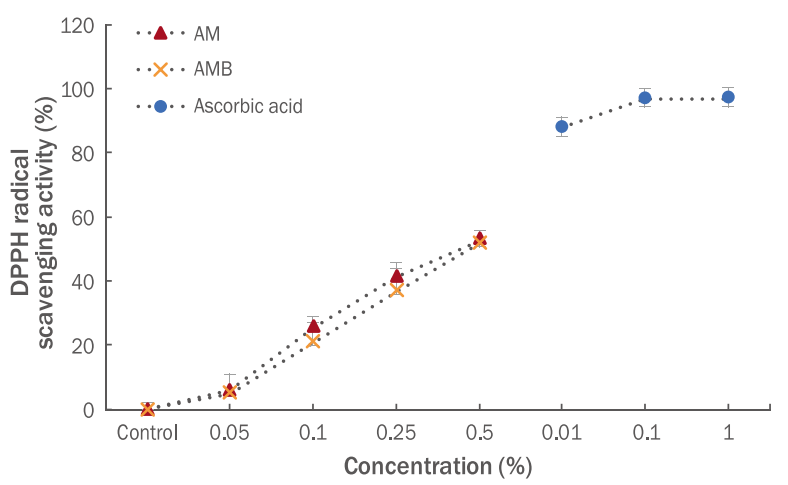

Figure 1. DPPH radical scavenging activity of AM and AMB.

Free radical scavenging activity was carried out so as to measure anti-oxidant activities of AM and AMB. Moreover, ascorbic acid was used as comparative material (positive control). In the result, it was verified that free radical scavenging activity of AM was higher than that of $A M B$. With regard to the value, a $M \pm S D$ is shown. Three independent experiments were performed. DPPH, 2,2-diphenyl-1picrylhydrazyl; AM, Astragalus membranaceus ethanol extracts; AMB, Astragalus membranaceus bioconversion extracts; Control, untreated group; $\mathrm{M} \pm \mathrm{SD}$, mean \pm standard deviation.

어 분석하였다.

\section{Results and Discussion}

\section{1. 항산화 효과 측정 결과}

특정한 혼합물 또는 식물 추출물의 자유 라디칼(free radical) 을 측정하여 항산화력을 검증하는 방법으로 $\mathrm{DPPH}$ 방법이 널 리 사용되고 있으며(Choi et al., 2003), 본 연구에서도 AM과 $\mathrm{AMB}$ 의 $\mathrm{DPPH}$ 라디칼 소거능을 확인하여 항산화력을 측정하였 으며, 결과를 Figure 1에 나타내었다.

본 실험 결과, 양성 대조군으로 사용한 ascorbic acid는 $1 \%$ 의 농도에서 $97.2 \%$ 의 높은 라디칼 소거 활성이 확인되었으며, $0.5 \%$ 농도에서 $\mathrm{AM} 52.7 \%, \mathrm{AMB} 51.7 \%$ 의 라디칼 소거 활성 을 확인하였다. Kim et al. (2007)은 $75 \%$ 에탄올 황기 추출물 에 가수분해 효소로 효소 처리하여 $\mathrm{DPPH}$ 를 측정하였으며, 두 시료 모두 $\mathrm{DPPH}$ 라디칼 소거능의 변화는 동일하다고 보고되고 있으며, 본 연구에서도 $\mathrm{AM}$ 과 $\mathrm{AMB}$ 의 추출방법에 따른 라디칼 소거 활성의 차이는 나타나지 않는 것으로 확인됨에 따라 본 연 구결과와 비슷한 결과를 확인하였다.

\section{2. 미백 효과 측정 결과}

1) B16F10 melanoma 세포에 대한 세포 생존율

$\mathrm{AM}$ 과 $\mathrm{AMB}$ 가 $\mathrm{B} 16 \mathrm{~F} 10$ 세포에 대한 세포 생존율에 미치는 영 향을 확인하기 위하여 $\mathrm{B} 16 \mathrm{~F} 10$ 세포에 $3.12,6.25,12.5,25,50$

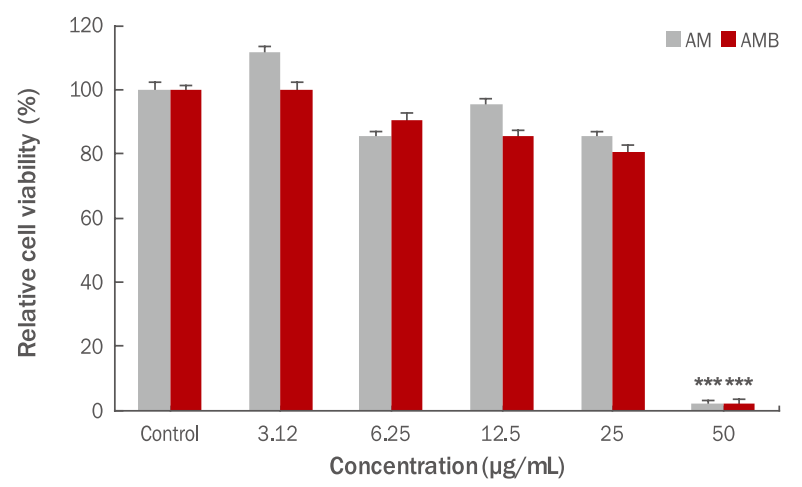

Figure 2. Cytotoxicity in B16F10 cells.

The cytotoxicity of AM and AMB was measured in B16F10 melanoma cells, and significant cytotoxicity was confirmed in the concentration of $50 \mu \mathrm{g} / \mathrm{mL}$. With regard to the value, a $\mathrm{M} \pm \mathrm{SD}$ was shown. Three independent experiments were performed $\left.{ }^{* * *} p<0.001\right)$. The results were compared between control group and experimental group. AM, Astragalus membranaceus ethanol extracts; AMB, Astragalus membranaceus bioconversion extracts; Control, untreated group; $\mathrm{M} \pm \mathrm{SD}$, mean \pm standard deviation.

$\mu \mathrm{g} / \mathrm{mL}$ 의 농도로 처리한 후 NR assay를 실시하였다(Figure 2). 본 실험 결과, $\mathrm{AM}$ 은 $111.5 \%, 85.5 \%, 95.6 \%, 85.5 \%, 2.1 \%$ 로 세 포 생존율이 확인되었으며, $\mathrm{AMB}$ 는 $100.0 \%, 90.7 \%, 85.8 \%$, $80.8 \%, 2.1 \%$ 의 세포 생존율이 확인되었으며, 두 시료 모두 $50 \mu$ $\mathrm{g} / \mathrm{mL}$ 농도에서 B16F10 melanoma 세포에 대한 유의한 세포 독 성이 확인되었으며, 이러한 결과를 바탕으로 추후 실험에서는 25 $\mu \mathrm{g} / \mathrm{mL}$ 이하의 농도로 실험을 진행하였다.

\section{2) 멜라닌 생합성 억제능}

$\mathrm{AM}$ 과 $\mathrm{AMB}$ 을 $3.12,6.25,12.5,25 \mu \mathrm{g} / \mathrm{mL}$ 의 농도로 $\mathrm{B} 16 \mathrm{~F} 10$ melanoma 세포에 처리하여 멜라닌 생합성 억제능을 측정한 결 과를 Figure 3 에 나타내었다. 본 실험 결과, 멜라닌의 생성을 촉 진시키는 것으로 알려진 $\alpha-\mathrm{MSH}$ 에 의해 멜라닌의 생성을 유의 하게 증가시켰으며, 양성 대조군으로 사용된 arbutin을 $100 \mu \mathrm{g} /$ $\mathrm{mL}$ 농도로 처리하였을 때(Kim et al., 2013), 23.4\%의 멜라닌 생합성 억제 효과를 나타내었다. 시료가 처리된 $25 \mu \mathrm{g} / \mathrm{mL}$ 농도 에서 $\mathrm{AM}$ 은 $23.0 \%, \mathrm{AMB}$ 는 $42.5 \%$ 의 높은 멜라닌 생합성 억제 효과가 확인되었으며, 특히 $\mathrm{AMB}$ 는 $3.12 \mu \mathrm{g} / \mathrm{mL}$ 의 저농도에서 arbutin과 유사한 억제 효과가 확인되었다. 이와 같은 결과를 통 해 $\mathrm{AM}$ 보다 생물전환된 $\mathrm{AMB}$ 에서 멜라닌 생합성 억제능이 우수 한 것으로 판단된다.

3) MITF, tyrosinase 발현량 변화

위의 실험에서 멜라닌 생합성 억제 효과가 뛰어난AMB 의 MITF와 tyrosinase의 단백질 발현량을 확인하기 위하여, 


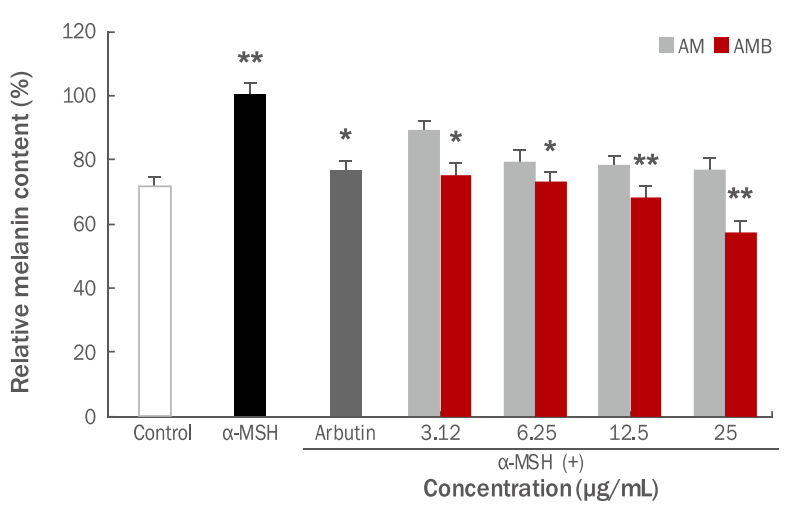

Figure 3. Ability of AM and AMB to suppress melanin synthesis in $\mathrm{B} 16 \mathrm{~F} 10$ cells.

B16F10 melanoma cells were treated with $100 \mathrm{nM} \alpha-\mathrm{MSH}$. AM and $A M B$ capacity to inhibit melanin synthesis was measured. Arbutin $(100 \mu \mathrm{g} / \mathrm{mL})$ was used as positive control group and the results were compared between $\alpha-\mathrm{MSH}$ group and experimental group. Results, Significant at all concentrations of AMB. With regard to the value, a $M \pm S D$ was shown. Three independent experiments were performed and statistical significance was shown ( $\left.{ }^{*} p<0.05 ;{ }^{* *} p<0.01\right)$. AM, Astragalus membranaceus ethanol extracts; AMB, Astragalus membranaceus bioconversion extracts; Control, untreated group; $\alpha-\mathrm{MSH}, \alpha-$ melanocytestimulating hormone; $\mathrm{M} \pm \mathrm{SD}$, mean \pm standard deviation.

B16F10 melanoma 세포에 $\alpha-\mathrm{MSH}$ 를 처리하여 멜라닌의 발현 을 활성화시키고, $25 \mu \mathrm{g} / \mathrm{mL}$ 농도의 $\mathrm{AMB}$ 를 처리한 후 Western blotting을 이용하여 MITF, tyrosinase 단백질 활성 억제 효과를 측정하였다(Figure 4), 본 실험 결과, $\mathrm{AMB}$ 에 의해 $\mathrm{MITF}$ 의 활성 이 $37.0 \%$ 감소되는 것이 확인되었으나, tyrosinase 억제 효과는 나타나지 않는 것으로 확인되었다. Joo et al. (2015)의 선행 연 구에서는 황기 추출물이 tyrosinase related protein 1 (TRP1),

A

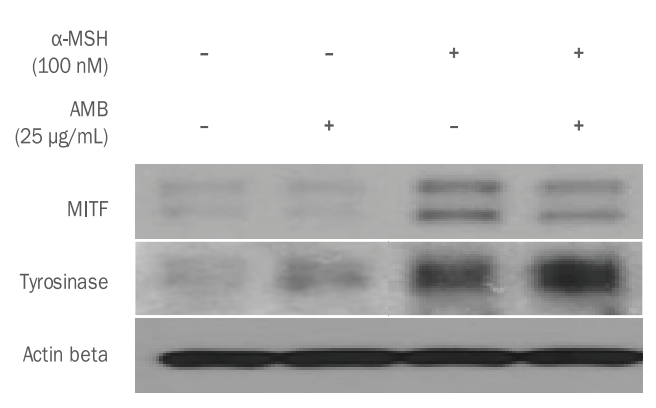

tyrosinase related protein 2 (TRP2), MITF, tyrosinase의 유 의한 감소 효과를 확인하였으며, Kim et al. (2011)은 황기 약침 액이 tyrosinase 활성을 통계적으로 유의하게 억제한다고 보고 함에 따라, tyrosinase 활성 억제 효과는 본 연구와는 다소 차이 가 있으나, MITF의 활성 억제 효과는 본 연구와 비슷한 연구 결 과가 확인되었다. 이와 같은 연구를 통하여 $\mathrm{AMB}$ 가 $\mathrm{MITF}$ 의 활 성 억제로 인한 미백 효과가 있을 것으로 사료된다.

\section{3. 항염증 효과 측정 결과}

1) RAW 264.7 세포에 대한 세포 생존율

$\mathrm{AM}$ 과 AMB가 RAW 264.7세포에 대한 세포 생존율에 미 치는 영향을 확인하기 위하여 RAW 264.7세포에 3.12, 6.25, $12.5,25,50 \mu \mathrm{g} / \mathrm{mL}$ 의 농도로 처리한 후 NR assay를 실시하 였다(Figure 5). 본 실험 결과, $\mathrm{AM}$ 은 $84.0 \%, 80.8 \%, 78.8 \%$, $69.6 \%, 41.4 \%$ 로 세포 생존율이 확인되었으며, $\mathrm{AMB}$ 는 $84.5 \%$, $80.9 \%, 99.0 \%, 58.8 \%, 40.0 \%$ 의 세포 생존율이 확인되었다. 또 한, $50 \mu \mathrm{g} / \mathrm{mL}$ 농도에서 두 시료 모두 RAW 264.7세포에 대한 유의한 독성이 확인되었으며, $25 \mu \mathrm{g} / \mathrm{mL}$ 농도에서도 $\mathrm{AMB}$ 의 독 성이 확인되었다. 이러한 결과를 바탕으로 추후 실험에서는 20 $\mu \mathrm{g} / \mathrm{mL}$ 이하의 농도로 실험을 진행하였다.

\section{2) RAW 264.7 세포에 대한 $\mathrm{NO}$ 생성 억제능}

$\mathrm{AM}$ 과 $\mathrm{AMB}$ 가 염증 반응의 중요한 인자로 알려진 $\mathrm{NO}$ 생성 억제 효과에 대하여 확인하기 위하여 RAW 264.7 세포에 염증 매개 물질인 LPS를 처리하여 세포 내 $\mathrm{NO}$ 생성을 유도한 다음 $\mathrm{AM}$ 과 $\mathrm{AMB}$ 를 처리하여 $\mathrm{NO}$ 생성 억제능을 측정하였다(Figure 6). 본 실험 결과, 모든 농도에서 농도 의존적인 $\mathrm{NO}$ 생성 억제 효과가 확인되었으며, 특히 $20 \mu \mathrm{g} / \mathrm{mL}$ 농도에서 $\mathrm{AM}$ 과 $\mathrm{AMB}$ 는

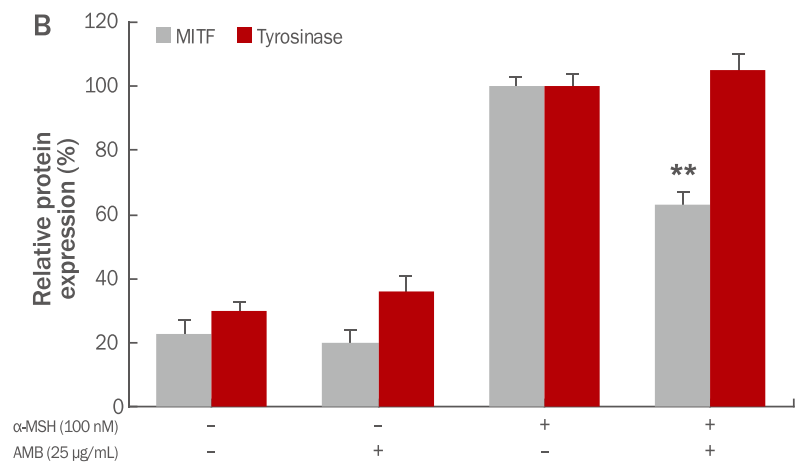

Figure 4. Inhibitory effects of AMB on MITF and tyrosinase activation in B16F10 melanoma cells.

(A) Image (B) Graph. In order to check the whitening effects of AMB, B16F10 melanoma cells were treated with $\alpha-M S H$. And an inhibitory effects of AMB on MITF, tyrosinase activities were measured by using western blotting. The results were compared between $\alpha-M S H$ group and experimental group and in MITF, significant inhibitory effects were checked. With regard to the value, a M $\pm S D$ was shown. Three independent experiments were performed $\left({ }^{* *} p<0.01\right)$. AMB, Astragalus membranaceus bioconversion extracts; $\alpha$-MSH, $\alpha$-melanocytestimulating hormone; MITF, melanogenesis associated transcription factor; $\mathrm{M} \pm \mathrm{SD}$, mean \pm standard deviation. 


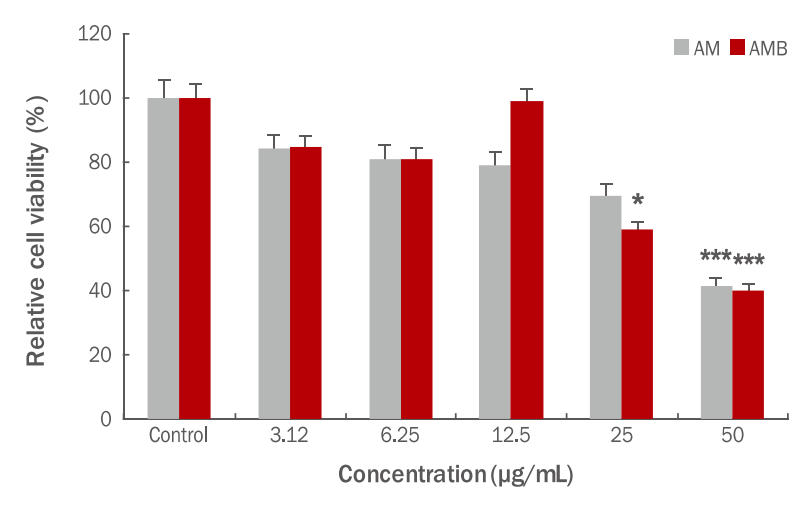

Figure 5. Cytotoxicity in RAW 264.7 cells.

The cytotoxicity of AM and AMB was measured in RAW 264.7 cells. The results were compared between control group and experimental group, and significant cytotoxicity was confirmed at the concentrations of $25 \mu \mathrm{g} / \mathrm{mL}$ and $50 \mu \mathrm{g} / \mathrm{mL}$. With regard to the value, a $\mathrm{M} \pm \mathrm{SD}$ was shown. Three independent experiments were performed $\left({ }^{*} p<0.05 ;{ }^{* * *} p<0.001\right)$. AM, Astragalus membranaceus ethanol extracts; AMB, Astragalus membranaceus bioconversion extracts; Control, untreated group; $\mathrm{M} \pm \mathrm{SD}$, mean \pm standard deviation.

$77.9 \%, 84.4 \%$ 의 유의한 억제 효과를 확인하였고, $\mathrm{AMB}$ 는 3.75 $\mu \mathrm{g} / \mathrm{mL}$ 의 저농도에서도 $38.7 \%$ 의 높은 $\mathrm{NO}$ 생성 억제 효과를 나타내었다. Mou et al. (2011)의 연구에서 황기 추출물이 NO 생성 억제에 중요한 작용을 하는 것으로 보고됨과 같이 $\mathrm{AM}$ 과 $\mathrm{AMB}$ 는 $\mathrm{NO}$ 생성 억제에 중요한 작용을 하는 것으로 사료되며, $\mathrm{NO}$ 생성 억제를 통한 면역기능조절과 다양한 피부 염증 반응을 효과적으로 억제하는 효과적인 물질로서의 활용 가능성이 있을 것으로 사료된다.

\section{3) RAW 264.7 세포에 COX2 발현 억제능}

위의 실험에서 $\mathrm{NO}$ 생성 억제 효과가 뛰어난 $\mathrm{AMB}$ 에 대하여 RAW 264.7 세포에 염증 매개 물질인 $1 \mu \mathrm{g} / \mathrm{mL} \mathrm{LPS}$ 를 처리하 여, 염증을 유도한 후 $20 \mu \mathrm{g} / \mathrm{mL} \mathrm{AMB}$ 를 처리하여 염증성 단백 질인 COX2 발현 억제 효과를 Western blotting을 통하여 확인 하였다(Figure 7). 본 실험 결과, $\mathrm{AMB}$ 는 $\mathrm{COX} 2$ 발현 감소에 큰 영향을 주지 않는 것으로 확인되었다. 이에 따라 $\mathrm{AMB}$ 는 $\mathrm{COX} 2$ 외의 다른 경로에 의하여 항염증 효과가 나타나는 것으로 사료 된다.

\section{Conclusion}

본 연구에서는 $70 \%$ 에탄올로 추출한 황기 에탄올 추출물 $(\mathrm{AM})$ 과 효소 처리를 통한 황기 생물전환 추출물 $(\mathrm{AMB})$ 을 이 용하여 항산화 활성 및 미백, 항염증 효과를 가진 기능성 화장

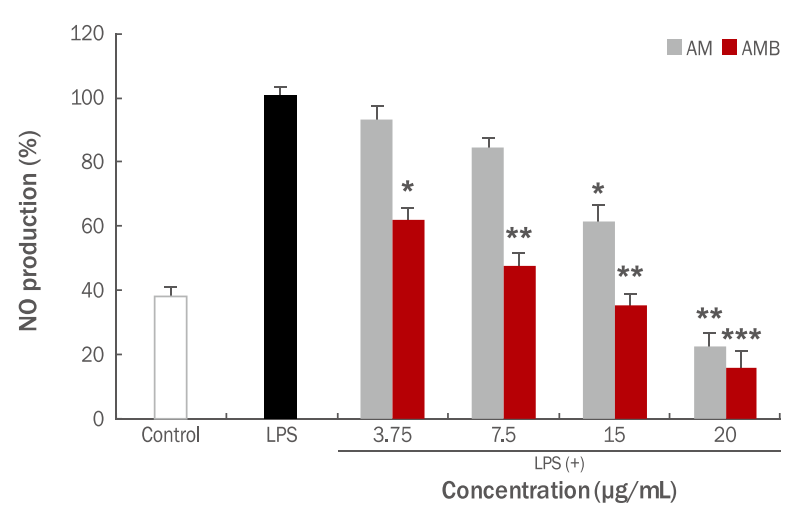

Figure 6. Inhibition of NO production in RAW 264.7 cells treated with $A M$ and $A M B$.

Activity was induced by treating RAW cells with LPS, and then inhibitory effects on NO production were measured by treating it with AMB. The results were compared between LPS group and experimental group, and an inhibitory effects on NO production were checked in all concentrations of AMB. With regard to the value, a $M \pm S D$ was shown. Three independent experiments were performed and statistical significance was shown $\left({ }^{*} p<0.05\right.$; $\left.{ }^{* *} p<0.01 ;{ }^{* * *} p<0.001\right)$. AM, Astragalus membranaceus ethanol extracts; AMB, Astragalus membranaceus bioconversion extracts; NO, nitric oxide; Control, untreated group; LPS, lipopolysaccharide; $\mathrm{M} \pm \mathrm{SD}$, mean \pm standard deviation.

품 소재로서의 생리활성 효과를 알아보고자 하였다. 본 연구 결과, $\mathrm{AM}$ 과 $\mathrm{AMB}$ 의 $\mathrm{DPPH}$ 라디칼 소거능은 비슷한 활성 효 과를 나타냄을 확인하였다. B16F10, RAW 264.7 세포에 대해 $\mathrm{AM}$ 과 $\mathrm{AMB}$ 의 세포 생존율을 측정한 결과, $\mathrm{B} 16 \mathrm{~F} 10$ 세포에서 는 두 시료 모두 $50 \mu \mathrm{g} / \mathrm{mL}$ 농도에서 유의한 세포 독성이 확인 되어 추후 실험에서는 $25 \mu \mathrm{g} / \mathrm{mL}$ 의 농도부터 실험을 진행하였 다. RAW 264.7 세포의 경우 $25,50 \mu \mathrm{g} / \mathrm{mL}$ 농도에서 유의한 세포 독성이 확인되어 추후 실험에서는 $20 \mu \mathrm{g} / \mathrm{mL}$ 농도부터 실 험을 진행하였다. 미백 활성 효과를 확인하기 위하여 멜라닌 생 합성 억제능을 측정한 결과, $\mathrm{AMB}$ 를 $25 \mu \mathrm{g} / \mathrm{mL}$ 농도로 처리하 였을 때 양성 대조군인 arbutin보다 높은 멜라닌 생합성 억제 효과가 확인되었고, 멜라닌 생합성 증가와 관련 있는 MITF 효 소를 $\mathrm{AMB}$ 가 효과적으로 활성 억제함에 따라 미백 효과를 확인 하였다. $\mathrm{AM}$ 과 $\mathrm{AMB}$ 의 항염증 효과를 확인하기 위하여 RAW 264.7 세포에 대한 NO 생성 저해 효과를 확인하였으며, 모든 농도에서 농도 의존적인 $\mathrm{NO}$ 생성 억제 효과가 확인되었고, 특 히 $\mathrm{AMB}$ 는 $20 \mu \mathrm{g} / \mathrm{mL}$ 의 농도에서 $84.4 \%$ 의 높은 $\mathrm{NO}$ 생성 억제 효과를 확인하였다. 하지만 염증 과정 중 형성되는 COX2 발현 억제와는 큰 영향을 주지 않는 것으로 확인됨에 따라 생체의 염 증 반응에 관련이 있다고 알려진 염증성 사이토카인 활성 억제 효과에 대한 추가적인 연구가 필요할 것으로 사료된다. 이와 같 은 결과를 통하여 $\mathrm{AM}$ 과 $\mathrm{AMB}$ 의 항산화 활성, 미백 효과 및 항 염증 효과를 가진 기능성 화장품 소재로서의 활용 가능성과 생 
A

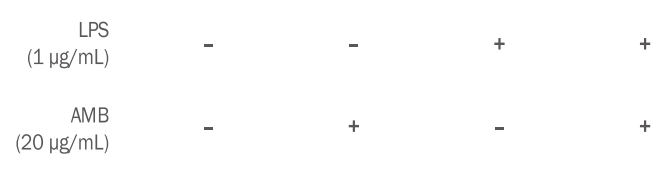

$\operatorname{cox} 2$

Actin beta



\section{B}

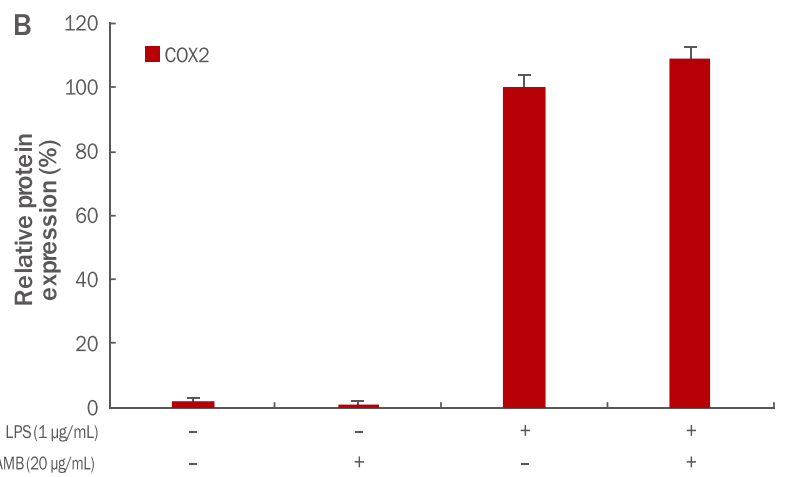

Figure 7. Inhibitory effects of AMB on the activation of COX2 by LPS in RAW 264.7 cells.

In order to check the anti-inflammatory effects of AMB, RAW 264.7 cells were treated with LPS, and inhibitory effects on COX2 activity were measured by using western blotting. The results were compared between LPS group and experimental group and COX2 activity was increased. (A) A variation of COX2 protein expression due to AMB was shown. (B) COX2 protein expression due to AMB was graphed. With regard to the value, a $M \pm S D$ was shown. Three independent experiments were performed and statistical significance was not shown. AMB, Astragalus membranaceus bioconversion extracts; LPS, lipopolysaccharide; COX2, cyclooxygenase 2; $\mathrm{M} \pm \mathrm{SD}$, mean \pm standard deviation.

물전환된 $\mathrm{AMB}$ 가 다양한 생리활성을 증진시켜 추출물의 유용 성과 효과성을 향상시킨 생물전환 화장품 소재로서의 활용 가 능성을 확인하였다.

This work is part of the Hye-Kyung Bae's Ph.D. thesis at the Konkuk University, Seoul, Korea.

\section{References}

Bang $\mathrm{KH}$, Huh MK, Cho JH. Genetic diversity and discrimination of Astragalus membranaceus Bunge and
A. membranaceus var. mogholicus using RAPD markers. Journal of Physiology \& Pathology in Korean Medicine, 18: 825-829, 2004.

Blois MS. Antioxidant determinations by the use of a stable free radical. Nature, 181: 1199-1200, 1958.

Choi Y, Kim M, Shin JJ, Park JM, Lee J. The antioxidant activities of the some commercial teas. Journal of the Korean Society of Food Science and Nutrition, 32: 723-727, 2003.

Green LC, Wagner DA, Glogowski J, Skipper PL, Wishnok JS, Tannenbaum SR. Analysis of nitrate, nitrite, and [15N] nitrate in biological fluids. Analytical Biochemistry, 126: 131-138, 1982.

Ha MJ, You SH. Bioactive characteristics of extracts of Opuntia humifusa fruit as functional cosmetic ingredients. Asian Journal of Beauty and Cosmetology, 14: 463-472, 2016.

Han DO, Kim GH, Choi YB, Shim I, Lee HJ, Lee YG, Kim JH, Chang GT, Hahm DH. Healing effects of Astragali Radix extracts on experimental open wounds in rats. Journal of Physiology \& Pathology in Korean Medicine, 19: 92-97, 2005.

Han HS, Kim SY, Lim DJ, Whang WK. Development of whitening cosmetic ingredients from Cudrania tricuspidata stem extract. Asian Journal of Beauty and Cosmetology, 14: 317-328, 2016.

Joo DH, Yoo DH, Lee SY, Lee JY. Whitening effect of Astragalus membranceus Bunge water extract and development of cosmeceutical. Jounal of the Korean Society of Cosmetology, 21: 888-894, 2015.

Jung TK, Kim MJ, Lim KR, Yoon KS. Moisturizing and antioxidation effect of Astragalus membranaceus root extract. Journal of the Society of Cosmetic Scientists of Korea, 32: 193-200, 2006.

Kang SA, Oh MS, Kim DR, Kang JU, Kim WN, Park EH, Chang MS, Park SK. Compositions of Astragali Radix and Angelicae Radix by DPPH radical scavenging activity. The Korea Journal of Herbology, 21: 17-24, 2006.

Kim EJ, Moon JS, Choe TB. Inhibition of tyrosinase by Bioconversioned Morus alba extract. Asian Journal of Beauty and Cosmetology, 11: 845-854, 2013.

Kim EJ, Yang KS. Effect of Astragali Radix on low density lipoprotein oxidation. Yakhak Hoeji, 45: 529-535, 2001.

Kim JH, Jung TY, Lee BH, Lee YK, Kim JS, Lee KM, Lim SC. Effects of Astragali Radix herbal acupuncture extracts 
on the collagenase activity and procollagen synthesis in HS68 human fibroblasts and tyrosinase activity. The Acupuncture, 28: 13-20, 2011.

Kim MJ, Lim KR, Jung TK, Yoon KS. Anti-aging effect of Astragalus membranaceus root extract. Journal of the Society of Cosmetic Scientists of Korea, 33: 33-40, 2007.

Lee JY, Park HY, Yeom MH, Kim DH, Kim HK. The protective effects of Astragali Radix against UV induced cellular damage in human keratinocytes. Korean Journal of Pharmacognosy, 39: 300-304, 2008.

Lim HW, Cho NY, Yoon MY, Cha SB, Kim KW, Park YM, Lee JY, Lee JH, Kim CJ, Sim SS. Effects of citrus essential oils on melanin production in B16 melanoma cells. Yakhak Hoeji, 47: 25-30, 2003.

Ma XQ, Shi Q, Duan JA, Dong T, Tsim KW. Chemical analysis of Radix Astragali (Huangqi) in China: a comparison with its adulterants and seasonal variations. Journal of
Agricultural and Food Chemistry, 50: 4861-4866, 2002.

McKenna DJ, Hughes K, Jones K. Astragalus. Alternative Therapies in Health and Medicine, 8: 34-40, 2002.

Mou JC, Lee SN, Kim MG, Kim MH, Kim HJ, Jo HJ, Leem KH. Effects of Astragali Radix extracts on the elastase activity and DPPH and NO scavenging activities. The Korea Journal of Herbology, 26: 59-63, 2011.

Ryu M, Kim EH, Chun M, Kang S, Shim B, Yu YB, Jeong G, Lee JS. Astragali Radix elicits anti-inflammation via activation of MKP-1, concomitant with attenuation of p38 and Erk. Journal of Ethnopharmacology, 115: 184-193, 2008.

Seo DM, Choi DY, Lee JD. Effects of Astragalus membranaceus on angiogenesis. The Acupuncture, 24: 113-123, 2007.

Yu HA, Kim CD. Applicability of Lindera obtusiloba flower extracts as cosmetic ingredients. Asian Journal of Beauty and Cosmetology, 15: 132-144, 2017. 


\section{국문초록}

\section{황기 에탄올 추출물 및 생물전환 추출물의 항산화, 미백, 항염증 효과에 대한 생리활성}

배혜경, 유선희

건국대학교 생물공학과, 서울, 한국

목적: 황기 에탄올 추출물과 생물전환 추출물의 기능성 화장품 소재로서의 활용 가능성을 확인하고자 하였다. 방법: 항산화 및 미 백, 항염증 효능을 확인하기 위하여 황기 에탄올 추출물과 생물전환 추출물의 2,2-diphenyl-1-picrylhydrazyl (DPPH) 라디칼 소 거능, 멜라닌 생성 억제능, melanogenesis associated transcription factor (MTTF)와 tyrosinase 발현량, nitric oxide (NO) 생성 억제 능, cyclooxygenase 2 (COX2) 발현 억제 효과를 측정하였다. 결과: 황기 에탄올 추출물과 생물전환 추출물의 두 시료 모두 0.5\% 농 도에서 $51 \%$ 이상의 DPPH 라디칼 소거 활성을 확인하였다. 두 추출방법 모두 뛰어난 멜라닌 생합성 억제 효과를 확인하였으며, 생 물전환 추출물의 MITF 발현 억제 효과를 확인하였다. 또한 생물전환 추출물은 우수한 NO 생성 억제 효과를 확인하였으나, COX2 억제 효과는 미비한 것으로 확인하였다. 결론: 항산화 활성 효과를 가지는 생물전환 추출물이 MITF 활성 억제를 통한 미백 개선 및 $\mathrm{NO}$ 생성 억제를 통한 항염증 효과를 가지는 다양한 기능성 화장품 소재로서의 활용 가치가 있을 것으로 사료된다.

핵심어: 항산화, 항염증, 황기, 생물전환, 멜라닌

\section{참고문헌}

강순아, 오명숙, 김도림, 강지웅, 김원남, 박은화, 장문석, 박성규. 當歸(당귀)와 黃茂(황기)의 배합 변화가 DPPH 자유기 소거 에 미치는 영향 연구. 대한본초학회지, 21: 17-24, 2006.

김미진, 임경란, 정택규, 윤경섭. 황기추출물의 항노화 효과. 대한화장품학회지, 33: 33-40, 2007. 김은정, 양기숙. 황기의 저밀도지질단백질(LDL)산화에 미치는 영향. 약학회지, 45: 529-535, 2001. 김은주, 문지선, 최태부. 상백피 추출물의 생물전환과 티로시나제 저해 효과의 비교. 아시안뷰티화장품학술지, 11: 845-854, 2013.

김지현, 정태영, 이봉효, 이윤구, 김재수, 이경민, 임성철. 황기 약침액의 사람 섬유아 세포에서 Collagen 생성과 Tyrosinage

활성에 미치는 영향. 대한침구의학회지, $28: 13-20,2011$.

모충정, 이세나, 김명규, 김명희, 김형준, 조학준, 임강현. 黃芪(황기)의 elastase 활성과 $\mathrm{DPPH}, \mathrm{NO}$ 소거능에 미치는 영향. 대

한본초학회지, 26: 59-63, 2011.

방경환, 허만규, 조준형. RAPD마커를 이용한 황기의 유전적 다양성 및 기원판별. 동의생리병리학회지, 18: 825-829, 2004. 서동민, 최도영, 이재동. 황기가 혈관 형성에 미치는 영향. 대한침구의학회지, 24: 113-123, 2007.

유현아, 김춘득. 생강나무 꽃 추출물의 화장품 소재로서의 응용 가능성. 아시안뷰티화장품학술지, 15: 132-144, 2017.

이진영, 박혜윤, 염명훈, 김덕희, 김한곤. 황기의 자외선에 의한 세포 손상을 막는 보호 효과. 생약학회지, $39: 300-304$, 2008.

임혜원, 조남영, 윤미연, 차상복, 김경원, 박영미, 이지윤, 이진희, 김창종, 심상수. B16 Melanoma 세포에서 Citrus Essential

Oil이 Melanin 생성에 미치는 영향. 약학회지, 47: 25-30, 2003.

정택규, 김미진, 임경란, 윤경섭. 황기추출물의 보습 및 항산화 효과. 대한화장품학회지, 32: 193-200, 2006.

주다혜, 유단희, 이수연, 이진영. 황기 물 추출물의 미백 효과와 기능성 화장품으로서의 개발. 한국미용학회지, 21: 888-894, 2015.

최용민, 김명희, 신정진, 박주미, 이준수. 국내 시판되는 일부 다류 제품의 항산화 효과. 한국식품영양과학회지, 32: 723-727, 2003. 
하민정, 유선희. 천년초 열매 추출물의 기능성 화장품 소재로서의 생리활성 특성. 아시안뷰티화장품학술지, $14: 463-472$, 2016.

한동오, 김건호, 최용복, 심인섭, 이혜정, 이용근, 김장현, 장규태, 함대현. 흰쥐의 외과적 창상에 대한 黃老(황기) 추출액의 치 료효과. 동의생리병리학회지, 19: 92-97, 2005.

한효선, 김수연, 임대진, 황완균. 꾸지뽕나무 가지 추출물을 이용한 미백 기능성 화장품 소재 개발. 아시안뷰티화장품학술지, 14: 317-328, 2016. 


\section{中文摘要}

\section{黄芪乙醇提取物和生物转化提取物的抗氧化、美白和抗炎作用的生理活性}

裴惠景 ${ }^{1}$, 柳宣熙 ${ }^{*}$

建国大学生物工学科，首尔，韩国

目的: 探讨黄芪乙醇提取物和生物转换提取物作为功能性化妆品原料的活用可行性。方法: 为确认黄芪乙醇提取物和生物 转换提取物的抗氧化、美白以及抗炎功效，测定2,2-diphenyl-1-picrylhydrazyl（DPPH）自由基消除能力、黑色素生成抑 制能力、melanogenesis associated transcription factor（MITF）和酪氨酸酶表达程度、一氧化氮（nitric oxide，NO）抑 制作用以及cyclooxygenase 2 (COX2) 表达的抑制作用。结果：黄芪乙醇提取物和生物转换提取物在 $0.5 \%$ 浓度下，都具 有51\%以上的DPPH自由基消除能力。两种提取物都具有良好的黑色素生成抑制作用, 并确认了生物转换提取物对MITF 表达具有抑制作用。此外，生物转换提取物具有优秀的NO生成抑制作用，但抑制COX2作用并不显著。结论：黄芪生物转 换提取物具有抗氧化作用, 通过抑制MITF活性改善美白效果以及通过抑制NO生成具有抗炎作用, 因此作为多种作用的化 妆品原料充分具有活用价值。

关键词: 抗氧化, 抗炎, 黄芪, 生物转换, 黑色素 